\title{
Education and Local Elite Authority: The Study of Traditional Local Elite Strategies in Maintaining Authority of Muslim Communities in Rural Java
}

\author{
Tadjoer Ridjal \\ Department of Sociology: University of Darul 'Ulum Jombang, Indonesia \\ Julian Adam Ridjal \\ Department of Agribusiness: University of Jember, Indonesia \\ Suko Susilo \\ Department of Da'wah, Islamic Institute of Tribakti Kediri, Indonesia \\ Humaidah Muafiqie \\ Department of Economics, University of Darul 'Ulum Jombang, Indonesia \\ Effy Indriati \\ Department of Agriculture: University of Darul 'Ulum Jombang, Indonesia
}

\begin{abstract}
The studies at village communities generally relate to poverty issues, circulation of village elites, formal village leadership and village community participation. Other studies discuss the determination of cultural values on agrarian differentiation, farmer resistance, and state interference in rural economy. This study relates with rural local elites, especially socio-religious field. The study focus is how the religious elites in villages maintain their authority. This study uses a qualitative approach. The study results show that although the village religious elite and their group members are no longer dominate the rural economy and control the formal village leadership, but this group still occupies a high level in society. One element dominated by group members from religious elite is education, especially religious knowledge.
\end{abstract}

Keywords: Education, Authority, Village Local Elites.

DOI: $10.7176 / \mathrm{JEP} / 12-2-09$

Publication date: January $31^{\text {st }} 2021$

\section{Introduction}

Previous rural studies, especially Java rural, usually more focused on life of rural communities based on problem of poverty. Such studies were conducted by Penny and Singarimbun (1972), Mubyarto, et al. (1984), Amaluddin (1987), Penny (1990), McCulloch et al (2007), Pattinama (2009), Sutopo, (2017) and Nasution, et al (2018).

Other studies focus on village humans in relation with circulation of village elites (Usman, 1990; Kauffman and Rudd, 2006; Choi, 2014) or formal village leadership (Fathoni, et al., 2015; and Alkadafi et al., 2018). The emphasis on issue of cultural value determination on agrarian differentiation was done by Rahman (1995), Annisa, et al (2009), farmer resistance by Suliadi (2015) and Putri (2017), and farmer resistance related to state interference in rural economy by Bertrand (1995) and Siahaan (1996),

This study focuses on local elites in rural areas. The studies of local elites generally examine the formal leadership or political elites in village. Khairul Amin (2017) explained the maps of the social relations between the community and village government and how the community participates in government itself. Meanwhile, Heru Cahyono (2005) focused on local political elites and other formal elites in village. Furthermore, Muhammad Fadli et al. (2018) examined the local political elites and religious and traditional leaders. Potluka and Fanta (2018) examined the role of formal and informal leadership in rural development.

This study follows up the findings of Ridjal (2004-a), Ridjal et al. (2019) and Ridjal et al (2020) related to local elites in religious field at rural areas, especially related to Islamic nuanced traditions. The dynamics of Islamic life in Java have been studied by Woodward (2004 and 2011). This study was conducted at a village within Jombang Regency, East Java Province. This study focus is the strategies undertaken by religious elites to build authority, especially to control the cultural life of their people. Therefore, the research question is "How do local elites in religious sector develop the authority to control the socio-religious life of community?"

\section{Framework and Methodology}

Identity and authority play a central role to implement the socialization function. One fundamental aspects of social interaction is some individuals have more influence than others. Social power can be defined as a person's ability 
to create conformity when the affected people may seek to oppose the change (Fiske, 1993; Keltner et al, 2003). People with large influence to control other people are shown by Stanley Milgram (1963). Milgram is interested toe examine the factors to make people obey the orders of people in authority.

To know the development of authority, it is necessary to recognize the background differences in social status in society, especially in rural areas. Differences in social status in rural areas were studied by Shedenova and Beimisheva (2013). Meanwhile, Wahyono (2017) stated that social stratification of Javanese society in rural areas in 19th century largely depended on land ownership patterns. Furthermore, Rahman and Selvijanti (2018) emphasize that relationships, communication and socialization in society is a social system created to makes the community divided into layers or positions based on beliefs, values, norms and customs in society.

The authority under study is classified as traditional authority. Mansur et al. (2013), Nasution (2017), and Ludeke et al (2013) also reviewed the traditional authority. The concept of elite from Laswell and Kaplan (1950) which stated, "... a class consisting of those who have succeeded to achieve domination in society, in sense that the created values receive high evaluation in the community". Furthermore, Soemardi (1991) added that ... these values may be in form of power, wealth, honor, knowledge, and others. Those who succeed have the most are called elites; the crowd the rest is the mass.

As for requirements for mastery of values, Laswell and Kaplan (1950) stated that elite manages to have the most of values because of their skills and personality traits. The accumulation of high ratings in society in certain groups or circles, they occupy a high position in social stratification system that lives in that community (Ridjal, 2004). Max Weber stated that social stratification is the classification of people belonging to a particular social system into hierarchical layers in according with dimensions of property, prestige and power (Waters and Waters, 2015).

This study uses a qualitative approach. The method used refers to directions of Miles et al (2014), Tracy (2013) and Yin (2011). Ridjal (2003) argued that study like this aims to explore or construct a proposition or explain meaning behind reality. Researchers stand on realities occurred in field. This study meets the social world of everyday life.

This study explores the phenomena in world and embeds the findings obtained in it. Therefore, the field research was done based on cases, ideography, and emics to pay attention to specifications of certain cases. The meaning of social phenomena, through the self-intersubjectives method, is emphasized but the objective conditions of socio-cultural life are not ruled out (Ridjal, 2003).

This study focuses the attention on everyday cultural life. The study area is emphasized on the cultural traditions that live in society. These cultural traditions are the basis for data collection. Furthermore, this study also pays attention to Anderson and Jack's (1991) statement that nature and level of community is largely a about individual definition. Therefore, data collection and the representation of study units emphasize on procedures to implement the underlie traditions and values, and more importantly the meaning of individuals as members of society towards traditions.

The data collection involves informants to clarify the field data for cross-checking field data. The collected data is interpreted by considering the informants' understanding. This allows for different interpretations of data about the same event. The researchers made a clarification by involving more informants, including informants who lived outside the study location village. Ridjal (2003) stated that such a step is a form of applying techniques for consistency and congruence of field data. Lincoln and Guba (1985) and Merriam (1995) used congruence term for internal validity, and consistency or dependability for reliability of qualitative data.

The researchers followed Adler and Adler's (1994) directions to get data collection with high level of consistency and congruence. The multiple observers' strategy is used to test the relevance of data through peer discussions and seminars, using various data collection techniques from various sources in study location situation. Data analysis takes place simultaneously with data collection process or through the stages of flow model from Miles and Huberman (1994), namely data collection, data reduction, data presentation, and verification that run simultaneously.

\section{Data Description and Discussion}

Geertz (1981) argued that structure of Javanese village society was generally under the joint influence of Islam and colonialism. Therefore, study of cultural life of Javanese rural communities cannot be separated from Clifford Geertz (1960) views in his work The Religion of Java. Geertz (1960) classified Javanese society into three cultural variants, namely santri, priyayi, and abangan, although the classification of Javanese cultural variants is still debatable. Legge (in Muchtarom, 1988) stated that such classification creates potential confusion the different categories, because in fact there is santri-priyayi or abangan-priyayi. Therefore, other experts emphasize that Javanese society is actually divided into two cultural parts, namely the santri group and abangan group (McVey, 1970).

This study was done in rural Javanese communities without neglect the cultural value system of "Javanese religion". However, this study does not completely follow Cliffort Geertz's view, but it also follows McVey's view. 
The community at study location, as pointed out by a number of villagers, initially consisted of gendera ijo (green flags or symbols of santri) and gendera abang (red flag or symbol of abangan). This refers to kirata for Jombang area name - an acronym for Ijo and Abang words. Kirata is word abbreviation of kira-kira ning nyata (guessed but real). It is a word processing strategy to achieve a meaning that "feels appropriate" (Ridjal, 2004-b), which in Javanese means cocog (Geertz, 1993). The term kirata has also been studied by Kholil (2009), Parsudi Suparlan (2006) and Tiani (2018).

The village community at study location in the next period was developed into three identity groups, namely Wong njero, wong njaba and wong mambu-mambu (Ridjal, 2004-a; 2019). Ridjal (2004-a) stated that Wong njero is a symbol of identity for members of kyai family, wong njaba is a symbol of identity to describes members of society who are politically and socially at lower strata, and most of village government officials generally come from circles symbolized as wong mambu-mambu. Based on kinship, members of wong mambu-mambu group consider themselves to have kinship with Wong njero. Meanwhile, those who come from wong njaba group consider themselves not to have direct kinship with other two groups, especially with Wong njero (Ridjal, 2004a).

Ridjal (2004-a) stated that the founder of the researched village was Mbah Kiai Isman. This is based on legends that have genealogical myths that live in village communities. The village founder is believed by villagers to be the descendant of Prince Alif, a Majapahit era cleric who was buried in Betek, Mojoagung. The legend is more of a folklore, or story of mouth from generation to generation. The folklore that Prince Alif was a noble in Majapahit era was not supported by valid empirical data. In fact, tombstone of Alif's grave was written the death was in 1700s, or in XVII century. The Majapahit palace had collapsed in 1400s, or the XIV century. Thus, Pangeran Alif was actually a noble in era of Surakarta Palace government. However, public believes more in truth of folklore story. Alif's grave is visited by many pilgrims, especially every Friday night.

Isman as a descendant of Alif become the founder of village and the village leader. After Isman passed away, village leadership was continued by his sons Hasani (religious affairs) and Abdul who was also called Mbah Muketar (village head). In The village leadership was continued by Hasani's sons, Nurman and Maskur. Nurman is trusted to control the leadership in religious sector, or as a village Kyai. Meanwhile, Maskur holds the formal leadership of village, as the village head. In next period, these two fields were controlled by Bari as Nurman's second son, since 1946 until he resigned as village head due to old age in 1989. After that, members of Wong njero family no longer controlled the formal village leadership or village head. However, leadership in religious sector or village kyai has remained under the control of members of Wong njero family from generation to generation.

There were two groups of people who were not kinship based on their descent during Isman's leadership. They are kadam (Kiai's helper) and migrants as agricultural laborers (Ridjal, 2004). The term kadam in this study is not much different from term studied by Ma'rifatun (2016), namely kadam. The kadam occupy the grant land, close to residential area of the Isman family. According to story of villagers, Hasani donated a yard of approximately $4000 \mathrm{~m} 2$ to a loyal kadam named Mukasip to be used by Mukasip's descendants forever, but with following conditions: (1) it cannot be sold, and (2) it cannot be inherited.

The migrants live at north of village. This location was donated by Isman. This is because most of residents who live in north of this village work as farm laborers, who work in rice fields and yards belonging to Isman family. Because they came from among wage workers, not from village founder, they were eventually given a symbol of identity as wong njaba. This story is stated by a number of community members who come from wong njaba circles, including the former maids in Nurman family. The characteristics distinguish the three groups of Isman family, kadam, and immigrants are agricultural land control, formal education, and especially the mastery of religious knowledge.

After Isman's two sons, Hasani and Abdul, village leadership was subsequently controlled by Hasani's two sons. They are Nurman and Maskur. The socio-religious life in this village greatly improved during the leadership of Nurman and Maskur. They established a pesantren, renovated a mosque, and built a family burial site behind the mosque. This village has been known by residents of surrounding villages as a santri village or religious kedhung, a local term for a center for religious teaching and learning activities, or pesantren. It is likened to kedhung (lake) because it can recede, which means that there is little water left; it is no longer the center because the descendants of Kiai's successors are less steeped in religious knowledge, or njero which means deep and watery; it means to remain as a center. The change in designation of village identity in turn encourages efforts to separate family descendants. It was at this time that terms that described local identities began to be put forward, which were initially associated with family descent backgrounds. These local identities are Wong njero, wong njaba and wong mambu-mambu. Thus, Kyai Nurman era was the early days where the differences in symbols of local cultural identity as Wong njero, wong njaba and wong mambu-mambu began to emerge.

Wong njero is a symbol of identity the members of Hasani family who have never been married to wong njaba. This group is believed to have advantages in terms of mastery of religious knowledge and a higher level of formal education than other circles. In addition, Wong njero is also symbolized as a controlling model for socioreligious and moral life. Therefore, every socio-religious activity such as recitation and various other slametans 
(alms) are always led by representatives from these circles, or at least leading prayers.

The Wong njero circles also receive special treatment in their daily interactions with other community members, especially with wong njaba circles. This can be observed from their nicknames which are always given the addition of article subasita, namely the nickname of respect. The article names for their names appear to be tiered. For men consisting of Mbah and Gus; while for women consist of Mbah, Ibu and Ning. With regard to such vocation, they generally feel that they are members of a civilized family group. In fact, according to them, term santri village or religious kedhung is seen as a reflection of community behavior. Although not exactly the same, this possibility is similar to opinion of Elias (1988) regarding the civilization process originating from code of conduct of palace life in Europe.

The control to agricultural land, formal education, and especially mastery of religious knowledge are predominate characteristics to distinguish the two groups. In early days of village, control of agricultural land was dominated by members of village's founding family, who were also ancestors of Wong njero community. Along with development of society, tenure of agricultural land is experiencing fragmentation. Members of Wong njero group no longer dominate to control the area of agricultural land. As for education --- both formal and informal -- it seems that members of Wong njero circles really care about it. In terms of formal education, information obtained from villagers stated that during the early days of independence, Nurman family had enrolled one of their sons in a public high school owned by Christian Foundation. The action of Nurman family was considered as a very brave act done by a Kyai at that time. In fact, this family also has an Islamic education foundation (madrasah) in Jombang. However, in afternoon and evening, child must recite religious knowledge at Islamic boarding school founded by Nurman.

Most of Wong njero family members attend to Islamic boarding schools and general education. They learn religious knowledge not only at pesantren in their village, but also in other schools in other areas. They also learn through formal education (public schools) and also non-formal education (reciting religious knowledge). However, recently, most children from Wong njero family prefer to study in formal schools and not live in pesantren. As for study of religious knowledge or the Koran he did in his hometown, taught by his own relatives who were alumni of pesantren.

The residents from Wong njero community have advantages in fields of religious knowledge and formal education than those from other circles. Wong njero community has symbolic legitimacy as a model for socioreligious and moral life, or considered as "role model". Every socio-religious activity, especially those related to traditional socio-religious rituals, as recitation, tahlilan, manakiban, nariyahan and dibaan are always led by representatives from these circles, or at least lead the prayers. This indicates that this group has authority in socioreligious field.

Friedman (1995) stated that identity and authority play a very crucial role in do the socialization function. As mentioned in introduction, during the early days of village the accumulation of resources to build the dimensions of stratification system - namely, property, prestige, and power - were controlled by Wong njero (Ridjal, 2004). In connection with phenomenon of social life, position of Wong njero in hierarchy of power has the authority to construct symbols of religious identity. With their identity and authority under their control, their capacities greatly support the function of socialization or enculturation, namely in transmitting their cultural values. Moreover, identity and authority are supported by people culture.

Anderson (1991), in Ideas of Power in Javanese Culture, describes the concept of power in culture using the contrasting method, namely the contrast between the concept of power in Javanese culture and concept of power in cultures in Europe and America. In Anderson's view, Javanese generally perceive power as energy that is sacred and sacred, but outside the person who uses it. Therefore, the power usage is automatic and has no moral implications and does not have quality requirements for a person.

Based on above conception, a Javanese leader will assume that as long as he controls the source of power alone, he has something that identical with power itself. Therefore, automatically he can also control the people. Anderson's view is also true if it is related to stories or legends in village community regarding the period when the separation between Wong njero and wong njaba began to come to fore. In addition, views of residents who state that ancestors of Wong njero as village founders also support symbolic legitimacy in sense of prestige towards the hierarchy of local level authority. What has escaped from Anderson's attention is that Javanese often express themselves in symbolic manner of ceremonies and speech. According to Koentjaraningrat (1991), Javanese conception of power as a sacred and sacred energy force was nothing but a symbolic conception. Magical nature is indeed an important condition for a Javanese leader, but it is not the only and not even the most important.

Based on this idea, the success of cultural values transmission process is supported by a relationship of authority. The concept of cultural transmission denotes the transmission of culture or widespread cultural elements: social orientation, skills, knowledge, and behavior. The scope of this distribution defines the boundaries of each culture. Research on transmission of intergenerational processes has focused on a various topics, such as gender roles in domestic work (Cordero-Coma \& Esping-Andersen, 2018), work values (Cemalcilar, Secinti, \& Sumer, 2018), trauma (Zerach, Levin, Aloni, \& Solomon, 2017), and academic self-concept (Mortimer, Zhang, Wu, 
Hussemann, \& Johnson, 2017). The theory of intergenerational cultural transmission stated that cultural ideas, beliefs, and practices are passed down from one generation to generation (Schönpflug, 2009). For example, Durham et al. (2009) examined intergenerational cultural transmission with a focus on language (Durham et al. 2009) and Trofholz et al. (2018) examined family eating habits.

The emergence of Wong njero identity symbol began at Nurman leadership. At that time, the only woman in Sumberarum who could read and write Latin letters and Arabic letters was Nurman's wife. In addition, first Sumberarum person to enter the pesantren education was Nurman. In fact, Nurman has become a student at several pesantren in East Java. The first pesantren that Nurman entered was the Mbah Kyai Kholil Bangkalan pesantren, Madura. And, last pesantren is the Mbah Kyai Zainuddin Cepoko pesantren, Nganjuk. Therefore, Wong njero identity symbol is also a manifestation of mastery of knowledge. Wong njero can also be interpreted as people who are njero (from Javanese which means: inside), which means literally: knowledgeable. This meaning is identical to Anderson's (1991) explanation of kalimasada story.

The accumulation of religious knowledge among the Nurman family becomes the supporting factor for members of this circle to occupy an honorable position at Sumberarum. High position in social stratification system gives these circles authority and symbolic legitimacy in an effort to dominate their influence. Conditions like this really support the various actions that lead to symbolization of this village as a "santri village", or religious kedhung. With this symbol, politically and culturally the Wong njero circles are becoming increasingly dominant.

\section{Conclusion}

The local sub-cultural identities in this research location create differentiation. Initially, these identities were relates with differences in descent groups and residential locations of its members. During the development, these local sub-cultural identities turned into status groups, although they did not lead to social class. This is based on social stratification system developed in this village.

The social stratification that lives and develops in village does not merely prioritize the differences in accumulation of wealth dimensions. Initially, social stratification in this village was based on differences in tenure of agricultural land. Most of agricultural land in village is owned by members of Wong njero group. However, when tenure of agricultural land experiences fragmentation, this group no longer controls rural agricultural land as in previous period. However, Wong njero identity still occupies a high social status. This can be observed from treatment of villagers to members of identity group.

The power dimension also shows this condition. In early days of emergence of differences in local subcultural identities, local village political elites were controlled by members of Wong njero group. This group controls the power (village head) in local political sphere and in socio-religious field (village kyai). However, since one of members of this group resigned as village head, due to old age, no member of this group has had the desire to run for village head. The position of village head has been controlled by residents who are not members of Wong njero identity group. Even so, members of Wong njero group still receive respect from villagers.

The Wong njero group no longer accumulates the dimensions of wealth and local political power as in early days of village. However, respect of villagers for members of this group has not changed. Based on a historical perspective, only dimension of stratification controlled by Wong njero that is not replaced by other groups is education. The first woman in this village who was not illiterate was from this circle. The first people who enter to pesantren (Islamic traditional school) were also from this circle. Attention to importance of education from this circle is higher than that of other circles. Therefore, authority which is still controlled by members of Wong njero group is the informal power. Since the beginning of village until today, village kyai has been controlled by members of Wong njero family. The supporting factor that is still controlled by this informal authority is the education sector. The Wong njero group's attention to education continues until today.

\section{References}

Adler, PA and P Adler, 1994, "Observational Techniques", in NK Denzin and YS Lincoln (ed), Handbook of Qualitative Research, London: Sage Publications, pp. 377-391.

Amaluddin M., 1987. Kemiskinan dan polarisasi sosial : studi kasus di desa Bulugede, Kabupaten Kendal, Jawa Tengah. Tesis, Jakarta : UIP.

Amanda C. Trofholz, Mai See Thao, Mia Donley, Mireya Smith, Hassan Isaac, Jerica M. Berge; February 2018, Family meals then and now: A qualitative investigation of intergenerational transmission of family meal practices in a racially/ ethnically diverse and immigrant population; Appetite, Vol 121, 1: Pages 163-172

Anderson, B, 1991, "Gagasan Tentang Kekuasaan Dalam Kebudayaan Jawa", dalam M Budiardjo (ed), Aneka Pemikiran Tentang Kuasa dan Wibawa, Jakarta: Pustaka Sinar Harapan, pp. 44-125.

Anderson, K and D Jack, 1991, "Learning to Listen: Interview Techniques and Analyses", in S Gluck and D Patai (ed), Women's Words: The Feminist Practice of Oral History, NY: Routledge, pp. 11-26.

Bertrand J, 1995, "Compliance, Resistance, and Trust: Peasants and the State In Indonesia", Dissertation, Princeton University. 
Boby Rahman, Ega Selviyanti, Oktober 2018; Studi Literatur: Peran Stratifikasi Sosial Masyarakat Dalam Pembentukan Pola Permukiman, Jurnal Planologi; Vol. 15, No. 2, 195 - 215.

D. H. Penny \& Masri Singarimbun, A Case Study of Rural Poverty, Bulletin of Indonesian Economic Studies, Vol 8 No. 1 March 1972, Pages 79-88

Deyra Qatrunnada Nasution; Yulmardi; Hardiani, 2018; Studi tentang kemiskinan di Kabupaten Batang Hari dan Kabupaten Muaro Jambi; e-jurnal Perspektif Ekonomi dan Pembangunan Daerah; Vol. 7. No. 2,: 79-90.

Dhanny Septimawan Sutopo , Kemiskinan Di Pedesaan Dalam Tinjauan Morfologi Sosial (Studi Kasus Kemiskinan di Desa Sumber Salak Kecamatan Curahdami Kabupaten Bondowoso Jawa Timur; Sosiohumaniora, Vol. 19 No. 3: 268-273.

Effendi Wahyono, Stratifikasi Sosial pada Masyarakat Pedesaan di Jawa Abad ke-19, 2017; Seminar Nasional Riset Inovatif: $305-312$.

Eric K. Kaufman and Rick D. Rudd; 2006, Rural Leadership Development: A Synthesis of Research; Journal of Leadership Education, Volume 5, and Issue 3: 128-141

Fiske, ST., (1993), Controlling other people: The impact of power on stereotyping. American Psychologist, 48 (6): 621-628.

Fitri Adri Yani, 2012, Tradisi Dhun-dhunan di Dusun Regeng, Desa Curugsewu, Kecamatan Patean Kabupaten Kendal, Skripsi, and Yogjakarta: UNY.

Friedman, J, 1995. "Global System, Globalization and the Parameters of Modernity". in M Featherstone, and S Lash, R Robertson (ed). Global Modernities, London: SAGE, pp 69-90.

Harold D. Lasswell and Abraham Kaplan. 1950, Power and Society; A Framework for Political Inquiry. New Haven: Yale University Press.

Heru Cahyono, Dhurorudin Mashad, Irine Hiraswari Gayatri, Moch. Nurhasim, Syafuan Rozi, dan Tri Ratnawati, (2005); Konflik Elite Politik di Pedesaan: Relasi antara Badan Perwakilan Desa dan Pemerintah Desa; Jurnal Penelitian Politik; Vol 2, No 1: 73-84

Jeylan T. Mortimer, Lei Zhang, Chen-Yu Wu, Jeanette Hussemann, Monica Kirkpatrick Johnson; March 2017, Familial Transmission of Educational Plans and the Academic Self-Concept: A Three-Generation Longitudinal Study; Social Psychology Quarterly, Volume 80 Issue 1, pp. 85-107

Julia Cordero-Coma - Gosta Esping-Andersen; August 2018, The Intergenerational Transmission of Gender Roles: Children's Contribution to Housework in Germany; Journal of Marriage and Family, Volume 80, Issue 4: 1005-1019;

Keltner, D., Gruenfeld, D H, \& Anderson, C.; 2003; Power, approach, and inhibition. Psychological Review, 110 (2): $265-284$.

Khairul Amin, Desember 2017, Elit dan Kekuasaan Pada Masyarakat Desa: Studi Relasi Antara Pemerintah dan Masyarakat di Desa Rias Kecamatan Toboali Kabupaten Bangka Selatan Provinsi Kep. Bangka Belitung; Jurnal Sosiologi USK; Volume 11, Nomor 2,: 167-187.

Koentjaraningrat. 1991. Metode Penelitian Masyarakat. Jakarta : Universitas Indonesia (UI-Press)

Laswell, HD, and A Kaplan, 1950, Power and Society: A Framework for Political Inquiry, New Haven: YUP.

Lincoln, YS, and EG Guba, 1985, Naturalistic Inquiry, Beverly Hills, CA: SAGE.

Luluk Annisa, Arif Satria, Rilus A Kinseng, 2009; Konflik Nelayan Di Jawa Timur : Studi Kasus Perubahan Struktur Agraria dan Diferensiasi Kesejahteraan Komunitas Pekebun di Lebak, Banten; Sodality: Jurnal Sosiologi Pedesaan, Vol. 3 No. 1: 113-124

Ma'rifatun, N; 2016, "Metabudaya Relasi Khodam dan Kyai : Studi Kasus di Pondok Pesantren Al Falah Ploso Mojo Kediri”, Tesis, Surabaya: UIN Sunan Ampel

Marcus J. Pattinama, Juli 2009; Pengentasan Kemiskinan Dengan Kearifan Lokal (Studi Kasus di Pulau BuruMaluku Dan Surade-Jawa Barat); Makara, Sosial Humaniora; Vol. 13, No. 1: 1-12

Mark Woodward, 2004, Islam Jawa: Kesalehan Normatif versus Kebatinan, Cetakan II, Yogjakarta: LkiS.

Mark Woodward, 2011, Java, Indonesia and Islam, New York: Springer.

Merriam, S. B., 1995; What can you tell from an $\mathrm{N}$ of 1 ? Issues of validity and reliability in qualitative research. PAACE Journal of Lifelong Learning, 4: 51-60.

Miles, Matthew B. and A. Michael Huberman, Johnny Saldana, 2014, Qualitative Data Analysis: A Methods Sourcebook and The Coding Manual for Qualitative Researchers; Thousand Oaks, CA: SAGE

Miles, MB, and AM Hubermann, 1994, "Data Management and Analysis Methods", in NK Denzin and YS Lincoln (ed), Handbook of Qualitative Research, London: Sage Publications, pp. 428-443.

Milgram, S. (1963). Behavioral study of obedience. Journal of Abnormal and Social Psychology, 67, 371-378.

Muammar Alkadafi, Safiah, Devi Deswimar; 2018, Analisis Kepemimpinan Kepala Desa Dalam Pengelolaan Desa (Studi Kasus Kampung Berumbung Baru Kecamatan Dayun Kabupaten Siak Provinsi Riau; Jurnal ElRiyasah, Volume 9 Nomor 2: 39-58.

Mubyarto, Soetrisno L, Dove M, 1984. Nelayan dan kemiskinan. Studi Ekonomi Antropologi di Dua Desa Pantai, Jakarta : Rajawali. 
Muhammad Fadli, Muh. Kausar Bailusy, Jayadi Nas, dan Achmad Zulfikar, 2018; Keterlibatan Elit Lokal dalam Peningkatan Partisipasi Politik pada Pemilihan Bupati dan Wakil Bupati Kabupaten Toraja Utara Tahun 2015 /06/; Sosial Politik Humaniora, Vol. 6. No.2: 301-328.

Mukhamad Fathoni, Suryadi, Stefanus Pani Rengu; Gaya Kepemimpinan Kepala Desa Dalam Pembangunan Fisik Desa (Studi di Desa Denok Kecamatan Lumajang Kabupaten Lumajang); Jurnal Administrasi Publik (JAP), Vol. 3, No. 1, Hal. 139-146

Mustafa Mansur, Kunto Sofianto, dan Dade Mahzuni; Maret 2013, Otoritas Dan Legitimasi Kedudukan Pemimpin Tradisional di Loloda Maluku-Utara (1808-1958); Sosiohumaniora, Volume 15, No. 1,: 64 - 72

Nankyung Choi, 2014, Local Political Elites in Indonesia: "Risers" and "Holdovers", Sojourn: Journal of Social Issues in Southeast Asia, Vol. 29, No. 2 (July 2014), pp. 364-407

Nazym Shedenova, Aigul Beimisheva, 2013, Social and Economic Status of Urban and Rural Households in Kazakhstan, Procedia - Social and Behavioral Sciences, No. 82: 585 - 591

Neil McCulloch, C. Peter Timmer and Julian Weisbrod, March 2007, Pathways out of poverty during an economic crisis: An empirical assessment of rural Indonesia; Working Paper; Center for Global Development, Number 115: $1-39$

Penny DH, 1990. Kemiskinan : peranan sistem pasar. Jakarta : UIP

Potluka, O., Fanta, P. (2018). Role of formal and informal nonprofit leadership in rural development. CEPS Working Paper Series, No. 14, Basel: CEPS.: 1-21.

Putri, Larasati Widi, 2017, Resistensi Petani Sayur pada Program Go Organik Studi di Desa Sumber Sejahtera Kecamatan Batu Kota Batu “. Thesis, Malang: Universitas Brawijaya.

Rachel E.Durham, George Farkas, Carol Scheffner Hammer, J. Bruce Tomblin, Hugh W. Catts, December 2007; Kindergarten oral language skill: A key variable in the intergenerational transmission of socioeconomic status, Research in Social Stratification and Mobility, Vol. 25, Issue 4: 294-305.

Rahman B, 1995, "Nilai Kultural dan Differensiasi Agraria di Pedesaan Jawa", Disertasi, Yogjakarta: UGM.

Ridjal, Tadjoer and Suharnan, Effy Indriati, Suko Susilo (2019); Santrinization and Egalitarian Spirit: A Case Study of Santri Village Community in Jombang, Indonesia, Historical Research Letter, Vol. 48: $29-36$.

Ridjal, Tadjoer, 2004-a, Tamparisasi Tradisi Santri Pedesaan Jawa, Surabaya: Kampusina

Ridjal, Tadjoer, 2004-b, Terkoyaknya Sebuah Mitos Di Balik Tumbangnya Sang Presiden: Sebuah Analisis MOAG Mayarakat Pinggiran Jawa Pedesaan, Surabaya: Kampusina.

Ridjal, Tadjoer, and Humaidah Muafiqie, Suko Susilo, Tri Susilowati, 2020, "Amalgamation in Rural Communities: Case Study for the Integration of Various Local Subculture Identities in Rural Java", Research on Humanities and Social Sciences, Vol.10, No.14,: 73-78.

Ridjal, Tadjoer. 2003. "Metode Bricolage Dalam Penelitian Sosial", Dalam Burhan Bungin (editor), Metode Penelitian Kualitatif, Aktualisasi Metodologis ke Arah Ragam Varian Kontemporer, Cetakan Kedua, Jakarta: PT RajaGrafindo Persada, Jakarta, hal. 82-100.

Robby Darwis Nasution, Juli 2017; Kyai Sebagai Agen Perubahan Sosial Dan Perdamaian Dalam Masyarakat Tradisional, Sosiohumaniora, Volume 19 No. 2: 177 - 184

Schönpflug, U., \& Bilz, L., 2009. The transmission process: Mechanisms and contexts. In U. Schönpflug (Ed.), Culture and psychology. Cultural transmission: Psychological, developmental, social, and methodological aspects, Cambridge University Press: 212-239.

Siahaan H, 1996. "Pembangkangan Terselubung Petani Dalam Program TRI Sebagai Upaya Mempertahankan Subsistensi". Disertasi, Surabaya: PPS UNAIR.

Soemardi, S, 1991, "Cara-cara Pendekatan Terhadap Kekuasaan Sebagai Suatu Gejala Sosial”, dalam M Budiardjo (ed), Aneka Pemikiran Tentang Kuasa dan Wibawa, Jakarta: Pustaka Sinar Harapan, pp. 30-42.

Steven Ludeke, Wendy Johnson, Thomas J. Bouchard Jr; August 2013, “'Obedience to traditional authority:' A heritable factor underlying authoritarianism, conservatism and religiousness; Personality and Individual Differences, 55 (4): 375-380

Suliadi, 2015, Resistensi Petani terhadap Pertambangan Pasir Besi di Karangwuni Kulon Progo; Jurnal Sosiologi Reflektif; Volume 9, Nomor 2,: 79-102.

Tracy, S; 2013, Qualitative Research Methods: Collecting Evidence, Crafting Analysis, Communicating Impact; Chichester, West Sussex,: A John Wiley \& Sons, Ltd., Publication

Usman S, 1991. Elit Desa dan Pembangunan: Laporan Penelitian, Yogjakarta : PAU Studi Sosial - UGM.

Waters, Tony, dan Dagmar Waters (2015), editor dan penerjemah. Rasionalisme Weber dan Masyarakat Modern: Terjemahan Baru tentang Politik, Birokrasi dan Stratifikasi Sosial . New York: Palsgrave MacMillan.

Yani, Fitri Adri (2012), Tradisi Dhun-dhunan di Dusun Regeng, Desa Curugsewu, Kecamatan Patean, Kabupaten Kendal,.S1 thesis, FBS UNY.

Yin, RK, 2011; Qualitative Research from Start to Finish; New York: The Guilford Press

Zerach, G., Levin, Y., Aloni, R., \& Solomon, Z., 2017. Intergenerational transmission of captivity trauma and posttraumatic stress symptoms: A twenty three-year longitudinal triadic study. Psychological Trauma: Theory, 
Research, Practice, and Policy, 9 (Suppl 1),: 114-121.

Zeynep Cemalcilar, Ekin Secinti \& Nebi Sumer, Aug 2018; Intergenerational Transmission of Work Values: A Meta-Analytic Review; Journal of Youth and Adolescence, Vol. 47 (8); 1559-1579 